\title{
兩周時期中國醫學的專業化小考
}

\author{
中國人民大學 歷史學院 歷史系 ${ }^{1}$
}

趙容俊 ${ }^{*^{*}}$

\section{A Review on the Specialization of Chinese Medicine in Zhou Dynasty}

\author{
Cho Yong Jun ${ }^{1^{*}}$ \\ ${ }^{1}$ Assistant Professor, School of History, Renmin University of China, CHINA.
}

Objective : The main idea of this article is to investigate the specialization of Chinese traditional medicine. The ancient shaman played a bridge role between human beings and supernatural things like ghosts. Even though he didn't have the super power, the ancients believed that he could take care of all kinds of illness. Therefore, it can be said that the medicine of Zhou Dynasty was still under the shamanism although it had already started to be specialized and professionalized. And it was the important role of the ancient shaman of that period that gave patients the shamanistic treatment on the ground of the specialized medical knowledge, which was commonly activated during that time.

Method : This article is going to look into the detailed aspects of the specialization of Chinese traditional medicine through the some kinds of written attestations of Zhou Dynasty.

Result : The medical knowledge of that time stayed in the early stage, so it was simple and raw. Also it had scientific and unscientific characters in itself at the same time. That's why it could be included in the shamanism; the details can be offered through another article of mine entitled A Research of Shamanistic Medical Activities on Written Attestations in the Zhou Dynasty(兩周時期的醫療巫術), which is being written now.

Conclusion : From beginning of the Eastern Zhou period, the medicine gradually got to be specialized. And then the specialized medical treatment and shamanistic medical activities began to be divided as the different two occupations. Searching for various written attestations of that period, we can see lots of records about the specialized medicine treatment such as acupuncture and moxibustion and the medical substances.

Key words : Zhou Dynasty, Traditional Chinese classics, Underground written attestations, Shamanistic treatment, The specialization of Chinese traditional medicine 


\section{I．序 論}

早在原始時期, 人類爲求得生存與種族的繁殖, 賏 對各種危害與影響人類生息健康的疾病的防治，則不斷 進行不解的探索。因此, 對於常見的外傷病徵, 古人已 有若干治療的知識。

於考古資料中多有揭示，至於夏商周時代，病徵、 病因識別已達相當水準1), 且醫療病患的方法與衛生保 健上的社會成俗, 一方面伴隨無數次成功或失敗的經驗 之積累, 在一定程度上標誌當時社會生活的文明發展狀 態, 與此同時, 又爲後世中國醫學體系的建立與完善, 則芫立其基礎2）。

即使如此, 原始社會生活條件艱苦, 食物低劣粗 䊁, 且衛生條件極差, 對人體組織起的慢性破壞作用, 確極嚴重。尤其, 在鬼神充斥時的許多遠古民族, 對於 不易得見之疾病的致因, 則直接歸諸自然界神祇的降災 或鬼在作崇。

因此, 古人爲消病除疫, 乃通常採取各種手段安拱 鬼魂, 或以祭祀討好之, 或以虔悔而消除鬼魂的不滿, 或表示屈服以取悅之, 或用某種儀式驅趕疫鬼。此時藉 助於能溝通人鬼間的媒介, 即巫者的力量而完成其 事3)。

古代巫醫不分, 由於人類將疾病致因視爲鬼魂作 用，故以巫者充當人鬼間的中介人角色，則寄希望於巫 術行醫、安撫死神而達於消除疾病的目的4)。因此, 於 舉行治病巫術儀式時, 巫者乃往往使出自己全部解數,

* 교신저자 : 조용준(趙容俊). 주소: 中國 100872 北京市 海 淀區 中關村大街59號 中國人民大學 歷史學院 歷史系.

E-mail : choyongjun@gmail.com

Tel :+86-137-1894-7020

접수일(2012년 10월 25일), 수정일(2012년 11월 18일), 게재확정일(2012년 11월 19일)

1）對於古人的病徵、病因識別水平的記述，如在《韓非子·五蛽 》中，便有其記載，其云：“ [上古之世， ] 民食果荿蜯(蛙) 蛤, 腥臊惡臭而傷害腹胃, 民多疾病。”梁啟雄. 《韓子淺解 》(下冊)第四十九篇《五蛽》. 中華書局. 1960. p.465.

2）詳見拙著. 殷商甲骨卜辭所見之巫術·先秦巫術的傳統及對後世 的影響(增訂本). 中華書局. 2011. pp.322-325. 亦可參見宋 鎮豪. 夏商社會生活史. 人生俗尚與病患醫療(增訂本、下冊). 中國社會科學出版社. 2005. p.711.

3）朱天順. 中國古代宗教初探. 鬼神崇拜與祖先崇拜. 上海人民出 版社. 1982. pp.181-188.

4）宋鎮豪. 夏商社會生活史.人生俗尚與病患醫療(增訂本、下冊). pp.743-756.
進行充分的表演，以完成此醫療巫術。正因基於此觀 念, 醫與巫, 醫療與巫術密切結合, 並且藥物心理與巫 術心理亦取得自然的結合，故求藥及求巫者之事，皆統 一於醫療活動之中5)。換言之, 古代的醫療知識, 仍然 處於中國醫學的萌芽狀態，古樸幼稚，科學與謬誤參 牛, 與巫教信仰交織一繫6)。

即使如此, 其後進入人文思想萌芽且發展中的周 代7)，古人逐漸脫離此種依賴巫者之迷信觀念8), 則以 針、尒以及藥物営之 ${ }^{9}$ ，而產生後世專業醫療之術及名 醫，如當時著名的專門醫生俞跗、醫緩、醫和、扁鵲 (即秦越人) 10)、文摰等。

5）對於求藥與巫術相結合以治病的情形, 許進雄在《中國古代社 會》一書中，曾提及三者之關係，其云：“在古代，巫最具實 用的能力是替人治病。……這是因営巫在行巫術時, 要使自己 精神達到恍惚、狂癲的狀態，才能使自己生幻覺而與鬼神對 話。那種境界很難只由唱歌、跳舞得到，還要借助藥力。有時 病人也要讓他服藥進入恍惚的狀況才能施術。巫對於疾病的反 應和治療的經驗遠較他人豐富, 對某些藥物與病徵的關係遞有 發現，很自然由之逐漸發展成爲善用藥物治療的醫生。故傳說 早期的名醫都具有巫的身分，《說文解字》說：“古者巫彭初 爲醫。”許進雄. 中國古代社會 -- 文字與人類學的透視(修訂 本). 臺灣商務印書館. 1995. p.506.

6）本文在定義上將巫教信仰與佛、道、基督教等的教團宗教不作 爲區別，則稱之爲“巫教”。拙著. 殷商甲骨卜辭所見之巫術·巫 義研究(增訂本). pp.23-58.

7）有關周代人文思想發展的情形，可參閱拙著. 殷商甲骨卜辭所 見之巫術·先秦巫術的傳統及對後世的影響 (增訂本). pp.284-293.

8）由於周代人文思想的萌芽與發展，不惟自周、秦以降巫者的政 治地位迅速降低，與此同時，擔任巫術性的活動，除巫者之 外，亦有稆、史、卜、宗、樂工等，分擔爲之。陳熾涁，左傳 中巫術之研究. 政治大學中文所博士論文. 1989. pp.94-133. 因此，於本文敘述中，除專門從事醫術的醫者之外，凡從事巫 術性醫療活動的人物, 則通稱爲“巫者”。

9）有關以針、炎、藥物治病的內容，於《春秋左傳·成公十年》 篇中，便有其記載，其云：“疾不可爲也，在肓之上，膏之 下，攻之不可，達之不及，藥不至焉。不可爲也。”(清)阮元 校刻。《十三經注疏(附校勘記)》(下冊)《春秋左傳》卷第二 十六《成公十年》. 中華書局. 1980. p.1906. 此外, 《禮記. 曲禮下》赤有其記載, 其云 : “君有疾, 飲藥, 臣先嘗之。親 有疾，飲藥，子先嘗之。醫不三世，不服其藥。”(清)阮元校 刻. 《十三經注疏(附校勘記)》(上冊)《禮記》卷第五《曲禮 下》. p.1268.

10）對於扁鵲的姓名，司馬遷則稱爲秦越人，如《史記·扁鵲倉公 列傳》便有其記載，其云：“扁鵲者，勃海郡鄭(鄚)人也，姓 秦氏，名越人。”(漢)司馬遷撰，(宋)裴馹集解，（唐)司馬貞索 隱, (唐)張守節正義. 《史記》(第九冊)卷第一百五《扁鵲倉公 列傳》。中華書局. 1959. pp.2785-2786. 即使如此, 若綜 合各種文獻所見的扁鵲故事，便知扁鵲的生存時間，已超越四 
因此，自東周始，受當時人文思想的影響，醫已逐 漸成專業而出現醫巫分爲兩項不同的職能。此種事實, 於兩周時期的各種文獻中，有關以針炎及藥物治病等的 醫學專業化的記載，即可見之。

本文以兩周傳世文獻及出土文獻所見之專業醫術與 醫學分科等記載爲主，敘述兩周時期醫學專業化的具體 內容。

\section{II. 本論：醫學的專業化}

\section{1. 兩周時期的醫術}

\section{1）醫巫兼施}

至於兩周時期，於先秦的古籍文獻中，有關當時並 行巫醫之法及專門醫術的記載, 則偶有所見, 如《春秋 左傳·成公十年》便有其記載，其云11）:

晉侯夢大厲，被髮及地，搏膺而踊曰：“殺余孫，不 義。余得請於帝矣！”壊大門及寝門而入。公懼，入於 室。又壞戶。公覺, 召桑田巫。巫言如夢。公曰: “何 如?”日：“不食新矣。”公疾病，求醫于秦。秦伯使醫 緩爲之。未至, 公夢疾爲二豎子, 日：“彼良醫也, 懼 傷我，焉逃之？”其一日：“居肓之上，膏之下，若我 何?”醫至, 日：“疾不可爲也, 在育之上, 膏之下, 攻 之不可, 達之不及, 藥不至焉。不可爲也。”公日：“良 醫也。”厚爲之禮而歸之。

由此可知，晉景公在求助於秦醫之前，先召桑田巫 占夢，此後秦醫醫緩，則以針、众以及藥物診病。

又《周禮·巫馬》亦云12)：

百年左右。因此，山田慶兒認営，此扁鹖故事，乃爲一種投影 理想醫者的傳說。其云：“[第一個作業假說］扁鹊傳說不僅 是遊方醫的傳說, 而且也是被理想化了的醫師的傳說。某時代 之醫師的理想像, 作爲在創造其像之人眼中視営最新、受到最 高評價之技術與理論的完整體現者，而被刻劃(畫)。……關於 扁鹊傳說的我的第二個作業假說, 可以表現如下。即, 在今日 所傳的扁鹊傳說中，具有其記述者之時代的醫學狀況與人僻對 醫學之願望的強烈投影。”山田慶兒著，廖育群，李建民編譯． 中國古代醫學的形成.扁荆傳說. 東大圖書公司. 2003. p.369.

11）(清)阮元校刻。《十三經注疏(附校勘記)》(下冊)《春秋左傳 》第二十六《成公十年》. p.1906.

12）(清)阮元校刻。《十三經注疏(附校勘記)》(上冊)《周禮: 夏官 司馬》第三十三《巫馬》. p. 861.
巫馬：掌養疾馬而乘治之，相(助)醫而藥攻馬疾，受 財于校人。

其下賈公彥疏云：“巫知馬崇，醫知馬疾，疾則以藥 治之，崇則辨而新之，二者相須，故巫助醫也。”13) 據此不難得知，巫、醫踓各有其專業與職掌，但巫、醫 本同職，故相須爲助14)。

不寧唯是, 又在(西漢)陸賈所撰的《新語.資質》篇 中，亦記載春秋時期巫、醫各施其術的情形，其 云15)：

昔扁鵲居宋，得罪於宋君，出亡之衛。衛人有病將 死者，扁鵲至其家，欲爲治之。病者之父謂扁鵲曰： “吾子病甚篤，將営迎良醫治，非子所能治也。”退而不 用，乃使靈巫求福請命，對扁鹊而呪，病者卒死，靈巫 不能治也。夫扁鵲，天下之良醫，而不能與靈巫爭用 者, 知與不知也。故事求遠而失近, 廣蔵(藏)而狹弃, 斯之謂也。

據此可知，於東周時期，施行專業醫療技術的醫 者，以及以巫術之法療疾的巫醫並存，且各施其術。

由此觀之，於兩周時期，此種專業醫療治病的知 識，與迷信治療的方法常交織一紫，遂成爲古代巫者擔 當的重要職責之一。此種巫者的醫療知識，於後世中國 醫學史的發展上，亦打上深深的烙印，則冊庸置疑 矣16)

\section{2）醫術的發展}

儘管如此，自東周伊始，受當時人文思想的影響, 則逐漸認識病因而形成醫學的專門化、職業化的趨向。 尤其，對於病因的認識，如《墨子·公孟》便有其記 載，其云17）：

13）同上.

14）林志鵬. 殷代巫晛活動研究. 臺灣大學中文所碩士論文. 2003. pp.65-69.

15） (漢)陸賈撰。《新語》卷下《資質》。 上海古籍出版社. 1990. pp.11-12.

16）有關巫者助力於後世醫學的發展，可參閱拙著．殷商甲骨卜 辭所見之巫術·先秦巫術的傳統及對後世的影響(增訂本). pp.322-325.

17）（清)孫詒讓撰，孫啟治點校。《墨子閒詁》(下冊)卷第十二《 公孟》. 中華書局. 2001. pp.463-464. 
子墨子有疾，……墨子曰：“雖使我有病，〔鬼 神] 何遽不明? 人之所得於病者多方, 有得之寒暑, 有 得之勞苦, 百門而閉一門焉, 則盜何遽無從入?”

又《春秋左傳·昭公元年》載醫和云18）：

天有六氣，降生五味，發爲五色，徵爲五聲。滛生 六疾。六氣日：院、陽、風、雨、晦、明也, 分爲四 時, 序爲五節。過則爲畄(災), 陰淫寒疾, 陽淫熱疾, 風淫末疾，雨淫腹疾，晦淫惑疾，明淫心疾。

\section{又《周禮·疾醫》赤云 19$)$ :}

疾醫 : 掌養萬民之疾病。四時皆有㾖疾: 春時有痟 首疾, 夏時有痒疥疾, 秋時有㠊寒疾, 冬時有漱( 刻)上 氣疾。

由此幾文可知, 古人在病因的認識上, 則多方面考 慮疾病現象的產生, 即認爲由自然因素與人身條件等的 原因而導致疾病。

隨著此種疾病原因認識的深化, 古人逐漸脫離鬼神 致病的觀念, 便形成醫者與醫術的專門化、職業化。對 此，如《荀子·法行篇》便有其記載，其云20）：

[子貢日 : ] “且夫良醫之門多病人, 隻栝之側多枉 木, 是以雜也。”

又《墨子·尚賢下》亦云21）:

王公大人有一罷(疲)馬不能治, 必索良醫。

又《管子·山權數》亦云22）:

18）（清)阮元校刻。《十三經拄疏(附校勘記)》(下冊)《春秋左傳 》卷第四十一《昭公元年》. p.2025.

19）(清)阮元校刻。《十三經注疏(附校勘記)》(上冊)《周禮·天官 冢幸》爸第五《疾醫》. p.667.

20）(清)王先謙撰, 沈曙寰, 王星賢點校.《荀子集解》(下冊)卷 第二十《法行篇》. 中華書局. 1988. pp.536-537.

21）（清)孫詥讓撰，孫啟治點校. 《墨子閒詁》(上冊)卷第二《尚 賢下》. p.67.

22）黎判鳳撰, 梁運華整理。《管子校注》(下冊)卷第二十二《山
［管子對曰：］“民之能已(止)民疾病者，置之黃金 一斤，直食八石。”

據此幾文不難得知，於東周時期，已有醫者與醫術 的專門化、職業化現象，與此同時，由此亦促進各種醫 療活動領域的日趨發展23)。

此處若論當時醫療技術的發展情形, 於先秦出土文 獻的記載之中, 此事便可得見。如在1975年末，在雲 夢睡虎地M11號墓葬發現的秦簡《封診式·庽(㾖)》篇 中，便有其記載，其簡文曰24）：

爱書: 某里典甲詣(送)里人士五(伍)丙, 告曰: “疑

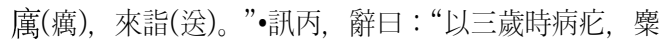
(眉)突(脫), 不可智(知)其可(何)病，四(無)它坐。”令 醫丁診之, 丁言日：“丙冊(無)糜(眉), 艮(根)本絕, 鼻 腔壞。刺其鼻不䟫(德)。肘㐨(膝) $\square \square \square$ 到 $\square$ 兩足下奇 (踦), 潰一所。其手冊(無)胧(髪)。令㗔(號)，其音氣 敗。庽(㾖)殹(也)。”(此簡文見於睡虎地秦簡《封診式 》第52簡至第54簡)

此篇記載里人士伍丙患瘦, 里人送府報告, 因而醫 丁觀察患者身體的各處, 乃診斷爲瘦疾。由此不難得 知, 戰國時期的醫者已施行專業的醫療診斷, 與此同 時, 又可瞭解已達於相當高水平的秦國醫術。

即使如此，醫踓已含有專門化、職業化的性質，然 而在中國古代社會中，仍未盡脫離古人巫醫之思想。例 如在周朝的文獻中, 以占卜探知致病之由的記載25), 則登實鬼神致病的觀念依然存在。由此亦可知，以巫術 之法療疾的情形，尚普遍存在於周朝社會之中。

由此觀之, 周代的醫療知識仍然處於中國醫學的萌 芽狀態，古樸幼稚，科學與謬誤參斗，與巫教信仰交織 一齔。即使如此, 此時的巫醫, 乃開拓壯大醫學的先 河，正因爲如此，巫醫在中國醫學上，則佔有重要的地

權數》. 中華書局. 2004. pp.1309-1310.

23）盧嘉錫總主編，廖育群等著. 中國科學技術史 -- 醫學卷·先 秦時期. 科學出版社. 1998. p.33.

24）睡虎地秦墓竹簡整理小組編. 睡虎地秦墓竹簡·封診式釋文註 釋. 文物出版社. 1990. pp.156-157.

25）(清)阮元校刻. 《十三經注疏(附校勘記)》(下冊)《春秋左傳 》卷第五十八《哀公六年》. p.2162. 其云：“初, [楚］ 昭王有疾, 卜曰: “河䋒崇。'王弗祭。大夫請祭諸郊。” 
位26)。

\section{2. 醫學的專業化}

\section{1）專業醫術}

如前言之，自東周始，受當時人文思想的影響，醫 已成專業而出現醫巫分爲兩項不同的職能。正如前面業 已所引，於先秦的古籍文獻中，有關以針炎及藥物治病 的記載，即可見之。如《春秋左傳·成公十年》記載晉 景公疾病，求醫於秦，秦伯使醫緩爲景公療疾，醫緩診 視後，謂景公云27）：

疾不可爲也，在肓之上，亳之下，攻之不可，達之 不及，藥不至焉。不可爲也。

又如(漢)韓嬰所撰的《韓詩外傳·第九章》亦記載, 扁鵲及其門徒在診治虢太子時, 便運用各種醫療之法, 其云28）：

扁鹊入，砥鍼礪石，取三陽五輸(會)，爲軒光之酧， 八減之湯，子同擣藥，子明尒陽，子游按摩，子儀反 神，子越扶形，於是 [虢] 世子復生。天下聞之, 皆以 扁鵲能起死人也。

由此不難得知，醫緩與扁鹊的治病，則以針尒、藥 物、按摩等數法爲之。此乃爲後世專業醫療之術。

又《周禮·醫師》亦有記載，其云29）

醫師：掌醫之政令，聚毒藥以共醫事。凡邦之有疾 病者、疲瘍者造焉，則使醫分而治之。

又《周禮·疾醫》亦云 30$) ：$

26）詳見拙著. 殷商甲骨卜辭所見之巫術·先秦巫術的傳統及對後 世的影響(增訂本). pp.322-325。

27）(清)阮元校刻。《十三經注疏(附校勘記)》(下冊)《春秋左傳 》参第二十六《成公十年》. p. 1906 .

28）(漢)韓嬰撰, 許維逅校䆁。《韓封外傳集䆁》卷第十《第九章 》. 中華書局. 2005. pp.347-348.

29）(清)阮元校刻。《十三經注疏(附校勘記)》(上冊)《周禮·天官 冢宰》卷第五《《醫師》. p.666.

30）(清)阮元校刻。《十三經注疏(附校勘記)》(上冊)《周禮·天官 冢幸》卷第五《疾醫》. p.668.
疾醫：……凡民有疾病者，分而治之。死終，則 各書其所以，而入于醫師。

此外，《周禮·愓醫》亦云 31$)$ :

瘍醫：……凡有瘍者，受其藥焉。

《禮記·曲禮下》又云32）：

君有疾，飲藥，臣先嘗之。親有疾，飲藥，子先嘗 之。醫不三世，不服其藥。

由此可知，於東周時期，已基本形成各種後世專業 醫療之術。

不寧唯是, 若視馬王堆出土的醫書《脈法》, 則多 反映先秦時期古人的經脈學成就33)，其中便有針炎療 法的記載，其文曰34）:

氣殹(也)者，到下一 $\square \square \square \square \square \square \square \square \square \square$ 焉。聽(聖) 人寒頭而煖足，治病者取有餘而益不足殹(也)。 $\square$ 上而 不下， $\square \square \square \square \square \square$ 過之 $\square$ 會環而久(尒)之。病甚，陽上 於環二寸而益爲一久(炎)。氣出焀(卻)與肘, $\square$ 一久 (尒)而 $\square$ 。用沰(挽)啟眽(脈)者必如式，雍(癱)穜(腫)有 馏(膿)，則稱其小大而 $\square \square$ 之。 $\square \square$ 有四〔害］：䀠 (膿)深 [而]沰(砣)戬(淺)，謂上(之)不還(及)，一害； 媳(膿)輚(淺)而沰(挽)深，胃(謂)之過，二害；腷(膿) 大 [而沰(砣)小]， $\square \square$ 而大 $\square \square \square ， 三[$ 害 ; 媳( 膿)］小而沰(挽)大，胃(謂)之㳓(挽) $\square$ ，沰(研) $\square$ 者， 石食(蝕)肉殹(也)，四害。（此文見於馬王堆帛書《脈法 》第72行中間至第77行下部)

據此可知，於馬王堆出土的《脈法》篇中，即可得

31）(清)阮元校刻。《十三經注疏(附校勘記)》(上冊)《周禮·天官 冢幸》第五《瘍醫》. p.668.

32）(清)阮元校刻。《十三經注疏(附校勘記)》(上冊)《禮記》卷 第五《曲禮下》. p.1268.

33）趙榉珊。中國古代醫學·馬王堆出土的醫學帛書. 中華書局. 1983. p.27.

34）馬王堆漢墓帛書整理小組編，馬王堆漢墓帛書脈法釋文注䆁 (肆). 文物出版社. 1985. p.17. 
見古人針砣35)、尒慰療法之術36)。

除此之外，亦有外科手術的記錄，如在《太平御覽. 醫四》中, 便記載秦醫醫竘切除痔核與化膿性疾患的內 容，其云37）

尸子曰：“有醫竘者，秦之良醫也。爲 [楚] 宣王割 痤, 営 [魏] 惠王療痔, 皆愈。張子之背腫, 命竘治 之。謂醫竘曰：“背非吾背也, 任子制焉。’治之, 䢒 愈。竘誠善治疾也, 張子委制焉。夫身與國, 亦唒此, 必有所委制，然後治。”

於此《太平御覽·醫四》的記載中, 便不難得知戰國 時期的醫者已行外科手術, 與此同時, 又可膫解已達於 相當高水本的秦國醫術38)。不寧唯是, 《戰國策·韓三 》亦云39) :

或謂韓相國日：“人之所以善扁鵲者, 爲有雍(癱)腫 也。使善扁鵲而無隹(㾿)腫也, 則人莫之爲之也。”

由此不難得知, 於戰國時期, 此種切除廐腫等的外

35）以古老的研石治痟腫者，如在《說文解字砣》字中，於 “阿, 追（以）石刺病也。从石，乏聲。”之下，其段注云： “以石刺病曰: 研, 因之名其石日：研石。《[山海經· 東 山經》: ‘高氏之山, 其下多箴石。’郭云: ‘可以爲兂針, 治 瘫腫者。” (清) 段玉裁注. 《說文解字注》第九篇注下 《研》. 藝文印書館. 1994. p.457. 又如《靈榀經.九針十 二原》亦云：“[歧伯答日：] ‘九針之名, 各不同形。一 日：鐿針，長一寸六分；二日：貟（員）針，長一寸六分； 三日：鍉針，長三寸牛; 四日：鋒針，長一寸六分; 五日： 鈹針, 長四寸, 廣二分牛 ; 六曰：貟（員）利針, 長一寸六 分; 七日：毫針，長三寸六分；八曰：長針，長七寸 ; 九 日：大針，長四寸。……鈹針者，末如㓣（劍）鋒，以取大 膿。”（唐）王冰注，（宋）史崧校正音釋、《霝樞經》笁第 一《九針十二原》, 載於 《文淵閣四庫全書》第七三三冊 《子部三九醫家類》。臺灣商務印書館. 1983-1986. pp.320-321. 由此可知，砣石乃鹪古老的針法所用之主要工 具。

36）盧嘉錫總主編, 廖育群等著. 中國科學技術史 -- 醫學卷·先 秦時期. p. 47 . 另見於馬繼興. 出土亡佚古醫籍研究, 中醫古 籍出版社. 2005. pp.320-323.

37）(宋)李昉等撰。《太平御覽》(第三冊)怣第七百二十四《方術 部·醫四》. 中華書局. 1960. p.3207.

38）山田慶兒著，廖育群，李建民編譯。中國古代醫學的形成。 pp.337-341.

39）（漢劉向集錄, 范硢雍笺登, 范邦瑾協校.《戰國策篦登》(下 冊)卷第二十八《韓三凡二十三章·或謂韓相國曰》。 上海古 籍出版社. 2006. pp.1613-1614.
科醫術, 已廣爲人所知。

不寧唯是, 又有精神療法的記錄, 如《吕氏春秋·至 忠》便有其記載，其云40）:

齊［淐］王疾病(痟)，使人之宋迎文摰。文摰至，視 王之疾，謂太子曰：“王之疾必可已(愈)也。雖然, 王 之疾已(愈)，則必殺摰也。”太子曰：“何故？”文摰對 日：“非怒王，則疾不可治，怒王則摰必死。”太子頓首 彊(強)請曰: “荷已(愈)王之疾, 臣與臣之母以死爭之於 王，王必幸(哀)臣與臣之母，願先生之勿患也。”文摰 日: “諾。請以死爲(治)王。”與太子期, 而將往不當 (至)者三，齊王固已怒矣。文摰至，不解履登牀，履王 衣，問王之疾，王怒而不與言。文摰因出辭以重怒王， 王叱而起, 疾乃遂已(愈)。

據此可知，戰國時期宋國的醫者文㙯，便從事“怒而 治愈” 的精神性疾病的治病 41 , 故醫史著作多引此作爲 精神療法之濫觞42)。

由此觀之, 兩周時期對於疾病的治療, 已俱備使用 藥物、針炎43)、按摩44）等數法, 以及外科治病與精神 療法之術。

40）王利器. 《吕氏春秋注疏》(第二姍)第十一《仲冬紀二二日 至忠》. 巴蜀書社. 2002. pp.1075-1079. 此外，此內容亦 可見於《論衡·道虚》篇。詳見黄俥撰. 《論衡校釋(附劉昐 遂集解)》(第二卅)告第七《道虛》。 中華書局. 1990. pp.326-329.

41）山田慶兒著, 廖育群, 李建民編譯。中國古代醫學的形成, pp.356-358.

42）盧嘉錫總主編, 廖育群等著. 中國科學技術史 -- 醫學卷·先 秦時期. p.82.

43）有關兩周時期以針刺治病的內容，除上引的先秦古籍文獻之 外, 亦在銅器銘文中, 即可見之, 如金文中的“俞(䶻、昐、 朌、㫜、5)”字，其字形以針與盤的組合。其意在於針刺皮 膚而以盤承接流出的血膿, 於血膿解除之後, 病即可痊愈。 故此“俞”字, 亦反映兩周時期以針刺治病的技術。許進雄編. 簡明中國文字學(修訂版). 中華書局. 2009. p.133.

44）有關兩周時期以按摩術治病的內容，如在馬繼興、周世榮合 著的《考古發掘中所見砣石的初步探討》一文中，便有其考 古報告, 其云：“1964年湖南益陽桃博戰國墓(M5)出土一件 凹面圓石，直徑3.2整米，內外兩面都有明顯的摩痕，凹槽 中能容納一手指指腹, 應是用於按摩體表的。”馬繼興, 周世 榮. 考古發掘中所見研石的初步探村. 文物. 1978(11)。 p.81. 


\section{2）醫學分科}

除上述的內容之外，隨著如上各種醫療技術的發 展，醫學分科亦逐漸形成，如《周禮·天官冢宰》記載 當時的官醫，則分爲食醫、疾醫、瘍醫、獸醫等四 科45)。

尤其，至於春秋戰國時期，此種醫學分科更爲具體 化，即出現婦產科、五官科、兒科等專科，則已有漸成 專門之勢。例如《史記·扁鵲倉公列傳》便有扁鵲在各 地成爲“隨俗”的專科醫者的記載，其云46)：

扁鵲名聞天下。過邯鄲，聞貴婦人，㴧爲帶下醫。 過雒陽，聞周人愛老人，師爲耳目痹醫。來入咸陽，聞 秦人愛小兒，師編小兒醫。隨俗爲變。

據此可知，於春秋戰國時期，醫術已分爲帶下、耳 鼻瘰、小兒科等的各種專科47)。

若舉其中婦產科爲例論之，於1973年，在長沙馬王 堆第3號漢墓中發現的馬王堆帛書中的一批醫書, 則多 反映先秦時期古人的各種醫學思維方式48）。其中《胎 產書》一篇, 乃屬於現今的婦產科, 則類似古醫書《產 經》，專論有關胎產的宜忌。其中一部分，乃爲後世徐 之才的《逐月養胎法》的祖本 49 )。

此《胎產書》篇中，便記載胎產宜忌的內容，其云：

- 禹問幼頻曰：“我欲埴(殖)人產子, 何如而有?”幼

45）盧嘉錫總主, 廖育群等著. 中國科學技術史 -- 醫學卷·先秦 時期. pp.52-53. 對於此四科所掌管的具體內容，詳見(清) 阮元校刻。《十三經注疏(附校勘記)》(上冊)《周禮. 天官冢 宰》第五《食醫》, 《疾醫》, 《瘍醫》, 《獸醫》。 pp.667-668.

46）(漢)司馬遷撰，(宋)裴駅集解，(唐)司馬貞索隱，(唐)張守節正 義. 《史記》(第九冊)卷第一百五、《扁鹊倉公列傳》. p.2794.

47）盧嘉錫總主編，廖育群等著. 中國科學技術史 -- 醫學卷·先 秦時期. pp. $52-53$.

48）許進雄. 中國古代社會 -- 文字與人類學的透䅐(修訂本). p.508. 其云：“近年在湖南長沙馬王堆發掘到一些古代的醫 學著作, 反映一些戰國時代的醫學成就。最早的抄本是秦、 漢之際的《五十二病方》。……我們可以想像漢代編輯的兩 部醫學名作《神農本草》和《黃帝內經》, 都是在戰國的醫 學基礎上發展起來的。”

49）馬王堆漢墓帛書整理小組編. 馬王堆漢墓帛書・出版說明(肆). p.3. 亦可參考盧嘉錫總主編，廖育群等著。中國科學技術史 -- 醫學卷. p.236.
頻合(答)曰：“月朔已去汁 $\square$ ，三日中從之，有子。其 一日南(男)，其二日女殹(也)。故人之產殹(也)，入於 冥冥，出於冥冥，乃始爲人。”(此文見於馬王堆帛書《 胎產書》第1行至第2行中間)50)

- 求子之道曰：“求九宗之草，而夫妻共以爲酒，飲 之。”(此文見於馬王堆帛書《胎產書》第28行)51)

此文中的“九宗”即九族，因九宗之草已凝聚大家族 的意志與力量，故任何妨礙生子的邪崇，均摧垮毀 滅52）。此雖爲屬於消極性的禁忌巫術，即使如此，古 人認爲如此能避無子之崇，且子棌繁衍。

由此可知, 於馬王堆醫書中的《胎產書》篇中, 不 惟記載逐月養胎之法及產婦調攝法, 又有巫術性質的求 子之法的內容53)。

不寧唯是，若就考古出土的文物而言，於山東、河 南等地出土的戰國時期古需印文中，亦可得見醫者分工 的細密情形。此處據陳直的古壐印文考登，略舉數例於 下，其云54）：

行瘖：(見《說文古篦補補》卷七，十頁)行字蓋從事 於醫的解釋。至今俗語稱醫生爲人治病日：行醫，或 日：行道。《說文》：“瘖，不能言也。”䨝文行瘖二 字，即是專治音(喑)嗝的病醫人所用。

事愓：(見《古爾文字徵》卷七，七頁)事字當作治字 解釋，(《史記·曹參世家》：“卿大夫以下及賓客見參 不事事。”下文有“惠帝怪相國不治事。”，可以爲登。） 謂專治瘍病的。《說文》：“瘍，頭創也。”創即後來的 瘡字。

事疕 $($ 音七)：(見《說文古㰖補補》卷七，十頁)《說 文》：“疕，頭瘍也。”當作專治頭掦的解釋，疑是現今 小兒頭上所患的臘瘡一類。

事㖁 : (見《說文古籀補補》卷七, 二頁)《說文》：

50）馬王堆漢墓帛書整理小組編，馬王堆漢墓帛書胎產書㩐文注 釋(肆). p.136.

51）馬王堆漢墓帛書整理小組編，馬王堆漢墓帛書·胎產書釋文注 釋(肆). p.139。

52）胡新生. 中國古代巫術. 山東人民出版社. 1999. p.501.

53）劉國忠. 古代帛書. 文物出版社. 2004. pp.111-112.

54）陳直. 文史考古論叢·需印木簡中發現的古代醫學史料. 天津 古籍出版社. 1988. pp.288-292. 
“痽, 腫也。”需文當作專治外症㿑腫病的解釋。

王瘖：(見《古爾文字徴》卷七，七頁)《說文》： “瘖, 不能言也。”上標明醫人的姓, 下標明醫人所專治 的病。

梁痖(音夾)：(見《古需文字徵》卷七，七頁）《說文 》: “撚，病息也。”需文是專切脈息的。

趙瘦 : (見《說文古篦補補》附錄十二頁)《爾雅·釋 訓》: “疾, 病也。”郭注 : “賢人失志懷憂病也。”爾文 是專治猶(憂)鍶病的。

牛瘍：(見《古雪文字徵》卷七, 七頁)壐文是專治牛 病的牛獸用的。《周禮·天官》有獸醫。蓋古代獸醫 中, 注重馬醫與牛醫。

據此不難得知，於戰國時期的私需中55)，每一醫者 乃治一病, 以發揮自己的專長, 故醫者的分工已相當細 密56)。

綜上所陳, 於兩周時期, 此種醫療治病的知識, 與 迷信治療的方法常交織一繫，透成爲古代巫者擔當的重 要職責之一。與此同時, 自東周始, 受當時人文思想的 影響, 醫逐漸成爲專業化, 並出現後世的專業醫療之 術。

\section{III. 結 論}

巫者職司交通鬼神，其本身雖不具超乎自然的力 量, 但古人相信巫者可藉鬼神之力以成就諸多事。古代 巫者其主要的活動類型, 可分爲交通鬼神、醫療巫術、 救災巫術、生產巫術、求子生育、建築巫術、喪葬巫 術、祝詛放蛊、神明裁判等九項57)。

古代人類，因生產條件極差，於野外勞動時，易受

55）對於戰國時期私爾的基本內容, 羅福顗在《古需印考略》中 曾提及, 其云：“戰國私鉨（需）：此時期的私鉨（需）， 有白文有朱文, 有鳌有鐥, 質地有銅、銀、玉。除姓名鉨 (需) 之外, 有成語鉨 (霥) 、肖形鉨 (霥) 。紐制一般多 是鼻紐，閒有亭縕、獸紐，有附帶鉤上者，也有二面印，成 語鉨（需）有五面者。他文字章法多得自然之風趣。”羅福

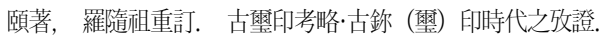
紫禁城出版社. 2010. p.87.

56）陳直. 文史考古論丵·需印木簡中發現的古代醫學史料. pp.288-292.

57）詳見拙著。殷商甲骨卜辭所見之巫術巫者的巫術活動(㒂訂 本). pp.77-108.
砍傷、摔傷或蛇蟲咬傷，因而已具有治療常見外傷病徵 的若干知識。由於經驗得知某種草藥對之有必然的療 效, 䌆能對證下藥, 故治療外傷的醫療知識, 透爲愈加 豐富。

即使如此，於遠古時期，由於地理環境惡劣，毒蛇猛 獸橫行, 加上生活熯苦, 且衛生條件極差, 故難免疾病的 時常發生。如前所述, 對於常見外傷病徵, 古人已有若干 治療的知識。儘管如此, 在鬼神充斥時的許多遠古民族, 對於不易得見之若干病徵, 則認爲此種疾病的來源, 乃爲 由㾽神、病鬼的䌕繞而造成, 即所謂鬼在作崇。

人類在經受各種疾病的苦惱中, 便尋求各種醫療巫 術的方法, 以排難解憂且脫離其桎梏。故召請巫者診 病，巫者則多採取問病卜災等占卜形式，乃診斷爲何鬼 所爲而驅鬼治病。

此種事實，於兩周時期，醫踓已含有專門化、職業 化的性質，然而在兩周社會中，仍未盡脱離古人巫醫之 思想。例如在周朝的文獻中，以占卜探知致病之由的記 載，則登實鬼神致病的觀念依然存在。由此亦可知，以 巫術之法療疾的情形, 尚普遍存在於周朝社會之中。

即使如此, 自東周始, 受當時人文思想的影響, 醫 已逐漸成專業而出現醫巫分爲兩項不同的職能。此種事 實，於兩周時期的各種文獻中，有關以針多及藥物治病 等的醫學專業化的記載, 即可見之。

本文則以兩周傳世文獻及出土文獻所見之專業醫術 與醫學分科等記載爲主，敘述兩周時期醫學專業化的具 體內容。此處以其扼要的內容總結如下。

第一, 於東周時期, 施行專業醫療技術的醫者, 以 及以巫術之法療疾的巫醫並存, 且各施其術。

第二，自東周伊始，受當時人文思想的影響，則逐 漸認識病因而形成醫學的專門化、職業化的趨向。

第三，兩周時期對於疾病的治療，已俱備使用燕 物、針尒、按摩等數法, 以及外科治病與精神療法之 術。

第四，於兩周時期，醫學分科亦逐漸形成，不惟當 時的官醫已分爲食醫、疾醫、瘍醫、獸醫等四科, 與此 同時，又出現婦產科、五官科、兒科等的專科，以及相 當細密的醫者分工。 


\section{徵引書目}

〈古籍文獻〉

1. (漢)司馬遷撰, (宋)裴馹集解，（唐)司馬貞索隱, (唐)張守節正義. 史記(全十冊)。 中華書局. 1959.

2. (漢)陸賈撰. 新語. 上海古籍出版社. 1990.

3. (漢)韓嬰撰, 許維過校釋。韓詩外傳集釋。中華書 局. 2005 .

4.（漢)劉向集錄，范样雍箋登，范邦瑾協校，戰國策 箋登(全二冊)。上海古籍出版社. 2006.

5.（唐）王冰注，（宋）史崧校正音釋。靈樞經，載 於《文淵閣四庫全書》第七三三冊《子部三九·醫 家類》. 臺灣商務印書館. 1983-1986.

6.（宋)李昉等撰. 太平御覽(全四冊)。中華書局. 1960.

7. (清)阮元校刻. 十三經注疏(附校勘記)(全二冊). 中華書局. 1980.

8. (清)孫詒讓撰, 孫啟治點校. 墨子閒詁(上、下冊). 中華書局. 2001.

9. (清)王先謙撰，沈嘯寰，王星賢點校．荀子集解 (上、下冊)。中華書局. 1988

10. (清)段玉裁注. 說文解字注. 藝文印書館. 1994.

〈中文參考資料〉

1. 王利器. 呂氏春秋注疏(全四冊)。 巴蜀書社. 2002.

2. 朱天順. 中國古代宗教初探. 上海人民出版社. 1982.

3. 宋鎮豪．夏商社會生活史(上、下)(增訂本)。中國 社會科學出版社. 2005.

4. 胡新生. 中國古代巫術. 山東人民出版社. 1999

5. 馬王堆漢墓帛書整理小組編. 馬王堆漢墓帛書 (肆). 文物出版社. 1985.

6. 馬繼興. 出土亡佚古醫籍研究. 中醫古籍出版社. 2005.

7. 許進雄. 中國古代社會 -- 文字與人類學的透視 (修訂本). 臺灣商務印書館. 1995.

8. 許進雄編. 簡明中國文字學(修訂版)。中華書局.
2009.

9. 陳直. 文史考古論叢. 天津古籍出版社. 1988.

10．黃睴撰．論衡校釋(附劉盼逐集解)(全四冊)。中 華書局. 1990

11. 睡虎地秦墓竹簡整理小組編。睡虎地秦墓竹簡。 文物出版社. 1990 .

12．趙容俊．殷商甲骨卜辭所見之巫術．文津出版 社. 2003 .

13．趙容俊．殷商甲骨卜辭所見之巫術(增訂本)。中 華書局. 2011.

14. 趙璞珊. 中國古代醫學. 中華書局. 1983.

15. 黎翔鳳撰，梁運華整理．管子校注(全三冊)。中 華書局. 2004

16. 劉國忠. 古代帛書. 文物出版社. 2004.

17．盧嘉錫總主編，廖育群等著。中國科學技術史 -- 醫學卷. 科學出版社. 1998.

18. 羅福匵著, 羅隨祖重訂. 古爾印考略. 紫禁城出 版社. 2010.

〈論文及其他〉

1. 林志鵬. 殷代巫梘活動研究. 臺灣大學中文所碩 士論文. 2003

2. 馬繼興，周世榮．考古發掘中所見䂵石的初步探 討. 文物. 1978(11).

3. 陳熾彬．左傳中巫術之研究．政治大學中文所博 士論文. 1989

4. 趙容俊. 先秦巫者的醫療活動研究. 清華大學歷 史系博士論文. 2010.

〈外國地區的參考資料〉

1. 山田慶兒著, 廖育群, 李建民編譯. 中國古代醫學 的形成. 東大圖書公司. 2003. 